\title{
ECONOMIC BENEFITS OF RISK SHARING
}

\author{
Abdul Karim Abdullah*
}

\begin{abstract}
Discussions of the benefits of risk sharing tend to be confined to benefits at the company level. These include remaining debt-free and the fact that capital, unlike borrowed funds - apart from listing, legal and other fees - comes at zero cost. What tends to be overlooked is that the use of risk sharing also brings major benefits to society at the macro-economic level. Specifically, it contributes to the realisation of the leading economic objectives of government stabilisation policies. These include an efficient allocation of resources, full employment, stable prices, robust growth, a more even distribution of wealth, and greater cyclical stability. Thus, channeling capital into investment by means of risk sharing in preference to borrowing at interest can significantly alleviate the macro-economic problems currently plaguing most industrialised economies.
\end{abstract}

\section{Introduction}

The extensive use of debt financing, compared to equity financing, is of relatively recent origin. Only with the rise of "financialisation" in the 1970s, characterised by increasingly lax regulatory regime and a laissez faire attitude on the part of regulatory authorities, did debt financing become the chief form of financing investment in most industrialised nations. Since the last (2007) economic and financial crisis, however, the disadvantages of debt financing are becoming increasingly clearer.

The root cause of the problem is the use of interest to motivate economic activity in preference to profit. The view that few major differences exist between interest and profit as incentives for allocating resources efficiently rests on an analysis of the underlying forces that motivate economic activity that is far from convincing. In other words, the problem is as much theoretical as well as practical.

The view that there is little difference between profit and interest facilitated not only the acceptance of interest as a legitimate incentive for motivating economic activity, but also the subsequent proliferation of debt over equity financing. However, the rapid increase in the utilisation of debt financing brought a range of harmful consequences.

Over the last few decades, nations that use interest as an incentive for the allocation resources have been sinking deeper and deeper into debt with no solution in sight. ${ }^{1}$ Social services are being scaled back as funds are being diverted from funding public services to repay loans with interest. Some governments, including that of the largest economy operate as it were on the verge of insolvency, with the threat of government shutdown due to insufficient funds being an ever-present threat. 
To make matters worse, many indebted nations have high levels of unemployment, significant inflation, and slow or declining economic growth. Added to this is the chronic instability caused by fluctuations in the volume of credit in the form of business cycles as well as an increasingly uneven distribution of wealth.

These problems can in principle be solved if their true cause is rightly understood, and suitable remedies are put in place. There needs to be greater awareness of the harm to society caused by interest-based financing and the corresponding benefits of the utilisation of risk sharing in financing economic activity.

The problems of the modern economies stem from the use of interest-based financing to fund consumption, investment and government spending. At a more basic level, they stem from the continued utilisation of the fractional reserve system of banking, without which interest-based financing would not be possible in the first place.

\section{Fractional reserve system of banking}

The fractional reserve system of banking allows financial institutions to operate with only a fraction of its short-term liabilities (deposits) in the form of liquid assets. This introduces a degree of instability into the banking system from the outset and exposes the bank to a risk known as the risk of a "run on the bank."

The fractional reserve system of banking also allows banks to operate outside of the real sector and gain interest income for their shareholders without contributing in any palpable way to economic activity (production). Moreover, the fractional reserve system of banking allows the financial institutions collectively to "create" money vastly in excess of the cash and coins in circulation.

"Created" money comes into existence as a result of bookkeeping entries made by financial institutions on their balance sheets. In other words, money "created" by financial institutions comes into existence without even being obtained in exchange for lending - the way interest income is gained. Apart from the ethical questions that permitting financial institutions to "create" money in this way raises, the fluctuations in the volume of "created" credit explains to a considerable degree the cyclical swings in economic activity.

The fractional reserve system not only allows financial institutions to "create" money without "earning" any part of it. It enables consumers, producers and even governments to spend money that has not been earned by anyone, including in particular the borrowers. ${ }^{2}$

The expenditure of created funds causes inflation, especially in the short term. In the longer term, financing expenditure using "created" funds has precisely the reverse effects. 
As borrowers repay loans with interest, the money borrowed and spent is gradually withdrawn from circulation. However, the total amount withdrawn over the entire cycle of borrowing, expenditure and repayment is invariably higher than the total initially injected into the real economy when borrowed funds were spent. ${ }^{3}$ One consequence of the excess of leakages over injections, over the entire cycle of expenditure of borrowed funds and their repayment is a contraction and a rise in unemployment that comes with it. ${ }^{4}$

Remedies that have been used to overcome recessions have brought mixed results. Attempts to accelerate growth using Keynesian stimulus spending amount to little more than solving one problem (unemployment) in the private sector by creating another problem in the public sector (fiscal deficit) or making it worse. The result is an increase in the national debt, reduced social services, and fewer funds left for development and the provision of public amenities.

The main reason for the ineffectiveness of conventional stabilisation policies is that nearly all analysis takes place within a fundamentally flawed theoretical framework. The major flaw in the Keynesian paradigm is the assumption that interest, as an incentive for ensuring an efficient allocation of resources, is no different from profit.

While Keynes has been rightly credited with the idea that the economy can experience equilibrium even at levels of less than full employment, he nevertheless remained firmly attached to the view that financing investment by borrowing at interest is not only ethically acceptable, but even economically sound in the sense that it helps to allocate resources efficiently. ${ }^{5}$

In fact, interest-based lending reduces the efficiency with which resources are allocated, and causes other harm besides. ${ }^{6}$ The reduction of efficiency manifests itself in a range of adverse effects. These include inflation, unemployment, slow or declining growth, uneven distribution of income and cyclical instability in the form of business cycles.

The realisation of the leading macro-economic objectives will thus require a re-structuring of the economic system. In particular, it will require phasing out interest-based financing and replacing it with risk sharing. The macroeconomic benefits of such a transformation would include an increase in the efficiency of the allocation of resources, stable prices, reduced unemployment, higher and sustainable growth, a more even distribution of wealth, and greater systemic stability.

\section{Interest and efficiency}

Investment is financed partly by using surplus funds known as "savings," or funds not spent on consumption. Savings can be channeled to business corporations 
directly by purchasing ordinary shares. They can also re-enter the real sector less directly by being first deposited in banks. Subsequently, banks make funds available to corporations in the form of loans at interest. These two forms of financing are known as equity and loan financing, respectively.

The volume of savings available for investment has important effects on economic performance. Surplus funds are used to finance long-term investment. This increases future productive capacity and holds out the prospect of a higher standard of living. However, it is not enough to generate a sufficient volume of savings. The savings need to re-enter the real sector.

If any part of the savings remains within the financial institutions, investment will be lower than would be the case if all savings re-entered the real sector. However, the financial system in its current form is structurally unable to recycle all savings in the real sector, and in that way realise an efficient allocation of resources. The reason for this is that under the current, interest-based regime, a part of the savings is prevented from re-entering the real sector. This diversion takes place as a result of the fact that banks offer guaranteed and predetermined interest income to parties with surplus funds. This interest income acts as a disincentive for investing in the risk-filled real sector.

With the prospect of gaining guaranteed interest income, and in amounts specified in advance, some investors - in particular those averse to risk - will prefer to deposit their surplus funds in financial institutions rather than take a risk in the real sector. This can happen even in cases where real sector returns may be higher than the interest offered by financial institutions. The reason for this is that, even though the interest income gained from financial institutions may be lower, it is guaranteed.

Another reason why not all savings deposited in financial institutions may find their way back into the real sector is that surplus funds can be re-cycled only after a qualified party is able to borrow them. ${ }^{7}$ A qualified borrower, in addition to posting acceptable collateral, needs to earn a minimum amount of profit. The availability of qualified borrowers may be limited.

A business needs to earn profit sufficiently high not only to pay interest, but also to repay the principal amount of the loan. Thus, earning a rate of profit that is at least equal to the rate of interest charged is not enough. A business that borrows at $8 \%$ per annum needs to earn profit on the capital borrowed that is higher than $8 \%$.

The reason is that repayments of the principal amount need to be factored into the repayment schedule. Thus, in order to repay a given loan over a tenyear period, with monthly repayments, a business needs to earn a minimum rate of profit equal to $14.5 \%$. This means that all businesses earning rates of profit lower than this will be automatically disqualified from obtaining the loan. 
In other words, loan financing effectively excludes all marginally profitable businesses from obtaining loan financing. This would appear to indicate that loan financing favours more efficient businesses, as these are generally also more profitable on account of their higher efficiency.

However, thin profits result not only from poor management; they are common in highly competitive industries. These include in particular the SMEs, the small and medium enterprises. Thus, financing businesses by lending tends to withhold loan financing precisely from businesses that most deserve to obtain them. The SMEs employ relatively large numbers of people. Restricting the flow of funds to SMEs thus makes the problem of unemployment worse. In this way, withholding investment funds from marginally profitable businesses reduces investment, employment and growth, all at the same time.

Equity financing, by contrast, has the opposite effects. When savings reach businesses in the form of investment, they come from and remain in the real sector. They are not withdrawn from circulation at any stage. The same, however, cannot be said about funds that enter the real sector in the form of loans. ${ }^{8}$ These come from banks and eventually return to banks.

\section{Risk sharing vs. risk transfer}

Entrepreneurs can obtain funds for investment by giving up a share of ownership of a business enterprise to investors in exchange for capital or by borrowing at interest. ${ }^{9}$ The first method requires the entrepreneur to take on partners and thus to share the ownership of his business and its profits with others. ${ }^{10}$ The second method requires the entrepreneur to borrow and repay debt with interest.

Each method establishes a different relationship between the counterparties. The first establishes a partnership, while the second establishes a creditor/ debtor relationship. ${ }^{11}$ Each impacts the counterparties as well as the economy in different ways. The impact of creditor/debtor relationships is generally harmful. By contrast, partnerships bring a range of benefits at both the company as well as the economic level.

Partners agree to share the risks of a given business enterprise as well as any profits or losses arising from it, as the case may be. ${ }^{12}$ The partnership has a common objective: to share risks, rewards and, if need be, losses. ${ }^{13}$ Their interests are closely aligned.

By contrast, lending does not oblige capital providers to become co-owners of the company they finance. This can make (secured) lenders indifferent to the relative success or lack of it of the companies they finance, as they hold no direct stakes in those companies. The interests of lenders and entrepreneurs, in other words, are only partially aligned. 
Lenders make funds available to entrepreneurs on condition that all funds be returned, along with a predetermined amount of interest, on a specific day in future. ${ }^{14}$ Lenders expect both their returns (interest) and capital (principal amount of the loan) to be guaranteed. They are risk averse.

In a creditor/debtor relationship business risks are confined (transferred) by capital providers (lenders) to entrepreneurs. This takes place by means of income and capital guarantees, which protect lenders from losses. ${ }^{15}$ The borrower must agree to these guarantees as a condition for obtaining the loan.

By contrast, in a partnership the entrepreneur is not obliged to return the investors' capital. Neither is he obligated to pay any rewards (dividends) to investors when the enterprise earns no profits. In this way, entrepreneurs who raise funds by means of risk sharing partnerships benefit from a reduced risk of bankruptcy. Entrepreneurs also benefit from remaining debt-free.

This holds true especially during economic downturns. Unlike parties that borrow to finance investment, entrepreneurs who raise funds on the basis of risk sharing are not legally obliged to maintain periodic payments to investors when their businesses earn no profits or incur losses.

Borrowers by contrast need to maintain repayments of loans in amounts determined in advance even during economic downturns, when they may be experiencing losses rather than earning profits. Moreover, borrowing obliges entrepreneurs to go into debt.

In other words, a creditor/debtor relationship is fundamentally different from a partnership. The lender shares the borrower's profits, but not his losses. Moreover, the lender's capital is guaranteed even if the entrepreneur were to go bankrupt. Should the borrower fail to make a single payment on time, he will be in default.

The rewards to investors and lenders are determined in different ways. Profit to investors is calculated as a proportion of total profit earned. However, the lender's share of the entrepreneur's profits (in the form of interest) is calculated as a proportion of the total amount of the loan. A specific percentage, unrelated to the efficiency of the business, is applied to the loan to arrive at the amount of interest that the entrepreneur must pay to the lender on dates specified in advance.

This means that the money paid in the form of interest, unlike profit, is not related in any way to the underlying efficiency of the business he is helping to finance by lending. This has far reaching implications on the efficiency with which resources can be allocated in a system that uses debt financing in preference to risk sharing modes of financing business investment. 


\section{Risk sharing}

Risk sharing is used in both Islamic and conventional finance. ${ }^{16}$ In Islamic finance, risk sharing takes place by means of partnerships known as the mudarabah and the musharakah. These partnerships issue certificates of ownership known as sukuk, normally for a specified period of time ${ }^{17}$ Participatory sukuk are similar to common shares. As partners, suppliers of capital share both risks and rewards with entrepreneurs. ${ }^{18}$

Risk sharing has a number of advantages. By pooling their resources, partners can increase the amount of capital at their disposal. This enables them to finance bigger projects. Partners can also offer advice to one another on the most effective ways to reduce the risks facing their business enterprise. Risk sharing also reduces the risk faced by any one partner. ${ }^{19}$ The greater is the number of partners sharing the risk the lower is the risk facing each partner.

By taking on a single equal partner, an entrepreneur reduces his risk by fifty per cent. When three parties share the risk (equally) the risk is reduced by two thirds of what a single party would have to bear. The greater the number of parties sharing the risk, the lower will be the risk facing each party. The amount of risk decreases as the number of partners increases. Partners can also obtain capital at a lower "cost" over the long term if they raise it in the form of equity than if they borrow. ${ }^{20}$

Where the partners actively participate in the running of the business, the partnership is known as a musharakah, or a profit and loss sharing partnership. A partnership in which capital suppliers do not participate in the management of the business is known as mudarabah or a profit sharing partnership.

The musharakah and the mudarabah partnerships are both fiduciary contracts. ${ }^{21}$ In the case of the mudarabah, the capital provider ( $\mathrm{rabb}$ al mal) trusts another party, the manager (mudarib) with faithfully discharging his duties and managing the entrusted capital to the best of his ability for the purpose of earning a profit. ${ }^{22}$ In the case of the musharakah, the capital provider exercises oversight over the management of the enterprise and may actively participate in managing it.

In conventional finance, risk can be shared by issuing and selling (common or ordinary) shares to interested parties (investors). ${ }^{23}$ These are (asset-backed) certificates of ownership that entitle their holders to a proportionate share of the company's profits. To sell its shares to the public, the business must offer convincing prospects of success and be led by a competent team of executives.

Shareholders are not guaranteed profits. ${ }^{24}$ As neither profits nor capital is guaranteed, investors face risks. The face the risk that they may earn no profits, and even that they might lose some or all of their capital. Investors can earn dividends only when their companies earn profits. However, risk has a positive 
role to play. It provides an incentive to investors to exercise due diligence before committing funds. This increases the overall efficiency in the allocation of resources.

Company shares can be traded in secondary markets. Their prices go up and down with the success of the company. Companies with strong prospects of success will attract more funding than companies with poor or limited prospects. Participation in companies on the basis of shareholding is permissible under the Shariah because it requires investors to share not only profits but also the risks of business enterprise.

Shareholders can exercise varying degrees of control over the enterprise they help to finance. They take a degree of responsibility for how the business is run. This responsibility is proportionate to the extent of their shareholdings in the issuing enterprise. While the shareholders leave the day-to-day management of the business to its managers, they can vote at shareholders' meetings in favour or against major decisions proposed by the management. ${ }^{25}$

\section{Economic rewards of risk sharing}

Risk sharing brings significant macroeconomic benefits. ${ }^{26}$ Overall efficiency in the allocation of resources increases because profit is linked to productivity. ${ }^{27}$ Financing by means of risk sharing also increases investment. An increase in investment takes place as a result of the fact that capital no longer comes at a "cost" (interest). Without the incentive to deposit surplus funds in financial institutions to gain interest, parties with surplus funds will have no choice but to invest in the risk-filled real sector, if they wish to obtain any returns on their capital.

An increase in investment can be expected to generate more employment, assuming other factors remain constant, as more workers will be required to operate new machinery and equipment. An increase in investment and employment in turn brings about an increase in economic growth. An increase in production (growth) furthermore can be expected to reduce inflation, as a result of an increase in the supply of goods and services relative to demand.

Greater systemic stability would result from the fact that the money used to finance an increase in investment would come from retained earnings and/or the issuance of investment certificates rather than from bank borrowings. Business firms that use retained profits to finance investment are also less exposed to the risk of bankruptcy, especially during economic downturns, as they are not legally obligated to pay dividends when they earn no profits.

Relying on internal financing helps prevent the formation of asset bubbles caused by excessive lending and thus restrain inflationary pressures. By obliging 
investors to take risk, gaining income by means of risk sharing also helps to distribute wealth more evenly, as there would no longer be any opportunity to gain "guaranteed" interest income. ${ }^{28}$

The need to take risk increases efficiency in the allocation of resources. Where investors feel there is little or no risk, they are more likely to commit resources on a scale greater than what is justified by a more accurate assessment of risks and the prospects of returns. This has taken place in the US housing market in 2008 and onwards, when institutional investors bought many of the so-called collateralised debt obligations (CDOs) or bundles of loans, which included subprime mortgages.

Millions of houses have initially been constructed financed by subprime mortgages, during a low interest period $(2002-2005)$. When interest started to climb in 2005, many house buyers could not make higher monthly payments as requested by financial institutions. ${ }^{29}$ They defaulted on their payments and the houses were repossessed. Subsequently the empty houses were torn down due to dilapidation. This was a manifestation of waste on an epic scale.

The need to face (share) risk filters out excessively risky investments. Illconceived projects are unlikely to attract funding. The fact that a given project is unable to attract funds by way of risk sharing shows that it should not be financed in the first place. As a consequence, "white elephant" projects are unlikely to attract funding. These benefits taken together constitute compelling reasons to adopt risk sharing as the choice method of financing, on a system wide basis. ${ }^{30}$

\section{Debt to equity}

Transforming the economy to operate on the basis of risk sharing requires restructuring financial institutions to operate as investment companies. In the case of financial institutions, this can be done by converting debt on both sides of a bank's balance sheet into equity. Former depositors become investors, while former borrowers become partners. In fact, a few of such institutions already exist. The "Euro Pacific Bank is a pioneer in transactional only banking. The bank maintains a $100 \%$ deposit ratio, makes no loans and does not engage in leverage or speculation with client assets." ${ }^{31}$

Such transformation would require enabling legislation. The desired transformation can also be helped using market forces. One incentive to financial institutions to operate in the real sector can be provided by amending the law to permit retailers (and manufacturers) to sell their goods directly to consumers on credit. This would put retailers in direct competition with financial institutions. As their costs are lower than those of the financial institutions, it would only be a matter of time before financial institutions (banks) would either be driven out of business, or forced to enter the real sector. ${ }^{32}$ 
However, the retailer's credit price would have to remain the same as the cash (spot) price. ${ }^{33}$ Even if not all retailers (or manufacturers) were to opt for this scheme, strong incentives exist for them to participate. While the need to administer payments on a deferred basis will add to the company's expenses, the prospect of higher sales resulting from lower prices would go a long way to compensate retailers and manufacturers for the extra burden of administering credit payments to the buyers. ${ }^{34}$

Direct selling is already practiced in a number of countries, by department stores and furniture sellers. If retailers can legally offer credit sales, there is no reason why housing developers or automobile manufacturers should not be able to do the same. The problem with the current practice is that the credit price is commonly significantly higher than the spot (or cash) price. The law needs to ensure that the credit price can only increase by a legally allowable margin, paid only for compensating the seller for the extra cost of administering credit sales.

The competition from companies making direct credit sales to customers would provide an incentive to banks to enter the real sector. Banks would be unable to sell goods at higher (marked up) prices, with the manufacturers selling the same goods on an installment (credit) basis at lower, manufacturers' prices.

Trading companies that operate on the basis of risk sharing would also become more stable. Unlike in conventional financial institutions, no structural mismatch could develop between liquid assets and short-term liabilities. Neither could a mismatch develop between the institution's assets and liabilities as a result of poor performance or non-performance of any of its assets. In a company that operates on a risk-sharing basis, both sides of its balance sheet rise or fall in tandem. Any losses on the asset (investment) side of the balance sheet are reflected (matched) on the liability side (investors' investments) of the company.

Investment companies would also become more stable as a result of not facing liquidity risk. This risk arises in conventional banking because banks use their depositors' funds to make loans at interest while guaranteeing those funds to depositors at the same time. ${ }^{35}$

For financial institutions that operate on the basis of risk sharing, there is no risk that depositors will withdraw their deposits in large numbers on a short notice. There is only the possibility that investors may sell (or liquidate) some of their investments to others. Such sales, however, would not drain liquidity from financial institutions the way withdrawals of deposits from a bank would.

They would only transfer the ownership of investments from one party to another, much like sales of common shares do. In such an environment, the main risk to investors is that their assets may decline in value. This is known as asset risk. Prudent asset management, rather than liquidity management, can go a long way towards ensuring that this risk will be minimal. 


\section{Conclusions and recommendations}

A start in transforming the system of incentives could be made by offering tax incentives to companies to use equity financing in preference to debt financing. Similarly, disincentives should be in place to discourage financing by borrowing. For example, payments of interest should no longer be treated as "expenses." This allows banks to reduce their taxable income and the amount of tax they pay. ${ }^{36}$

A tax should also be placed on all transactions in derivatives. ${ }^{37}$ Apart from reducing the flow of funds into the unproductive credit sector, a tax such as this would also raise extra revenues for governments and thereby help to reduce its debt.

In an interest free system there would be no need to "bail out" failing financial institutions at great taxpayers' expense and increasing the debt burden on future generations. The practice of privatising gains and socialising losses would be reduced.

Neither would governments have to go into debt as a result of having to finance counter cyclical fiscal policies. Transfer payments to unemployed individuals will also be smaller than in economies with higher employment levels. As a result of stronger growth and less unemployment, governments can collect higher tax revenues. These constitute compelling reasons for adopting financing risk sharing on a system wide basis.

Legislation needs to be implemented to facilitate the economic transformation to risk sharing modes of financing. Important benefits of financing investment by risk sharing include higher systemic stability and a more efficient allocation of resources. Raising funds on the basis of risk sharing would also enhance investment, reduce unemployment and improve economic growth.

Prices should also be more stable in an environment where producers have no need to pass on interest expenses to their clients in the form of higher prices, and where financial institutions are unable to make loans simply by "creating" funds.

Risk sharing also ensures an efficient allocation of resources and a reduction of waste by providing investors with a powerful incentive - the risk of losses - to exercise due diligence. At the same time, by requiring a greater number of parties to share risks, risk sharing enhances systemic stability. These constitute compelling reasons for utilising risk-sharing contracts in preference to risk transfer modes of risk management.

- It is recommended to adopt financing by risk sharing in preference to loan financing.

- It needs to become easier to raise investment funds by issuing shares or participatory sukuk. Red tape needs to be reduced or eliminated. 
- Banks and other financial institutions need to reinvent themselves as trading companies that operate on the basis of risk sharing rather than risk transfer (in the form of secured lending).

- A regulatory framework needs to be implemented that rewards and facilitates the issuance of securities that share risk rather than transfer it.

- The law needs to be amended to encourage investment by risk sharing. Tax advantages need to be transferred from lenders to entrepreneurs.

\section{Endnotes}

* Abdul Karim Abdullah (Leslie Terebessy), Assistant Fellow at IAIS, earned his MA in political philosophy from the University of Toronto, Canada (1999) and a MEd (1986) from the University of Toronto's Ontario Institute for Studies in Education (OISE). A former lecturer, editor, writer and coordinator of the English programme at University Sains Islam Malaysia (USIM), his current projects involve research into the current financial crisis, critical thinking in Muslim societies, and Islamic Finance. He has edited Islamic Studies at World Institutions of Higher Learning (Kuala Lumpur: USIM 2004). He can be contacted at abdulkarim@iais.org.my.

1. This applies to both the public as well as the private sector.

2. We may note in passing that, since most of the money loaned by financial institutions is "created" rather than "earned," it is only partly true that financial institutions act as "intermediaries" between parties with a surplus of funds (savers) and parties that experience a shortage (borrowers), by channeling the savings of the former to meet the needs of the latter.

3. The reason why a greater amount of money is withdrawn from circulation during the repayment stage than is injected into it when borrowed funds are spent is that all borrowed funds need to be repaid with interest.

4. Standard economic theory teaches that whenever leakages from the circular flow exceed injections, a contraction (decline) in economic growth will take place. This decline can take the form of a reduction in the rate of growth, or even the form of an absolute decline in the GDP from one accounting period to the next.

5. I have elaborated the weaknesses of this assumption in "The Pitfalls of Riba or Interest-based Financing," ICR, Vol. 4, No. 1, January 2013.

6. We use the term "efficiency" in its macroeconomic sense, in which it means producing goods and services that meet people's needs without generating any persistent surpluses or shortages. Thus, evidence of efficiency in the macroeconomic sense would include stable prices, full employment, and robust growth.

7. A qualified borrower is one who is able to post acceptable collateral and who earns profits sufficiently high to repay the loan with interest over a specified period of time.

8. We draw a distinction between lending and investment. The former takes place when capital is advanced on condition that it be repaid, and that rewards (interest) 
be specified and guaranteed in advance. The latter takes place when investors share risks with entrepreneurs. In other words, investment takes place on the basis of risk sharing, without income and capital guarantees.

9. The combination of debt and equity financing is known as the "capital structure" of the firm. In addition, entrepreneurs can use their savings or retained earnings to finance business investment.

10. Capital can be raised by selling common shares or stocks to interested investors. "Shares" are asset-backed certificates of ownership in the issuing enterprise. They can be sold privately or on a stock exchange. Buyers of the shares become co-owners of the business in proportion to their investments. As co-owners of the business, they become entitled to a proportionate share of its profits.

11. Mirakhor, Abbas "Risk Sharing and Public Policy," INCEIF, Paper prepared for the 5th International Islamic Capital Market Forum Securities Commission of Malaysia, 10 November, 2011, Kuala Lumpur, Malaysia, p. 14.

12. Humayon A. Dar and John R. Presley, "Lack of Profit and Loss Sharing in Islamic Banking: Management and Control Imbalances," International Journal of Islamic Financial Services Vol. 2 No. 2, September 2000, p. 3, accessed online on 20 June 2014; <http://www.iefpedia.com/english/wp-content/uploads/2009/09/ international-journal-of-ISLAMIC-FINANCIAL-SERVICE.pdf>

13. In France, business communities are known as "societies."

14. Repayment of loans can also be amortised, meaning that the entire loan, inclusive of interest, will be repaid in installments.

15. Risk transfer is present in, but not restricted to, all forms of collateralised lending at interest. Risk transfer is also utilised in insurance as well as in derivatives, including options, credit default swaps, and interest rate swaps.

16. For a comprehensive overview of risk sharing, see Mirakhor, Abbas "Risk Sharing and Public Policy," INCEIF, Paper prepared for the 5th International Islamic Capital Market Forum Securities Commission of Malaysia, 10 November, 2011, Kuala Lumpur, Malaysia.

17. Agha, Oliver Ali and Claire Grainger "Analysis: Sukuk - When is a default not really a default?" Risk.net, 11 December 2009, accessed online on 15 March 2013, <http://www.risk.net/credit/analysis/1565919/sukuk-default-default>

18. Shoaib, Nabeel, "Top 500 Islamic Financial Institutions - From Niche To Mainstream," The Banker, November 2007, p. 1, accessed online on 15 March 2013, <http://search.proquest.com.myaccess.library.utoronto.ca/ docview/225624269\#>

19. Kamali, Mohammad Hashim, Islamic Commercial Law: An Analysis of Future and Options, Ilmiah Publishers, 2000, p. 209.

20. By this we mean that the issuer is not obliged to commit himself to making predetermined payments of interest. Of course, listing costs, legal fees and various taxes do impose some costs on entrepreneurs who issue certificates of investment to investors, whether it be in the form of participatory sukuk or common shares. These types of costs are only incurred once, unlike payments of interest, which are recurring over the entire course of the repayment of a loan. When the accumulated interest expenses are compared to the initial listing and other costs, the latter become dwarfed by the former.

21. Jobst, Andreas A. "The Economics of Islamic Finance and Securitization," 
Working Paper Version: February 28, 2007 Forthcoming in the Journal of Structured Finance (2007), Vol. 13, No. 1, p. 6, accessed online on 19 January 2013, <http://www.kantakji.com/fiqh/Files/Markets/f178.pdf>

22. Kapetanovic, Harun and Muhamed Becic "Mudharabah Sukuk: Essential Islamic Contract, Applications and Way Forward," in Sukuk, Abdulkader Tomas, (ed.), Securities Commission Malaysia, Sweet and Maxwell Asia, Thomson Reuters, 2009, p. 226.

23. What is the difference between "risk sharing" and "profit and loss sharing?" The term "risk sharing" signifies the "sharing of risks and rewards." But "rewards" may sometimes take an unwelcome form, namely that of losses. "Risk sharing" understood in this way thus implies that there is little difference between "risk sharing" and "profit and loss sharing." In some arrangements, however, such as in mudarabah partnerships, only profits are shared, but not losses. These are borne exclusively by the capital provider ( $r a b b$ al mal). Thus, mudarabah partnerships are profit sharing partnerships rather than profit and loss sharing ones. In Islamic finance, a "profit and loss sharing partnership" in known as a musharakah, in which profits are shared according to a pre-agreed profit sharing ratio, but losses are shared in proportion to capital invested.

24. The so-called "preferred" or "preference" shares constitute something of an anomaly, as they combine some features of bonds, such as giving priority to holders of preferred shares over holders of common shares in the payment of dividends, and some features of common shares, such as that the payments of dividends are not guaranteed as interest payments are, but are paid only when profits are earned.

25. This varies from business to business, and also depends on how active the shareholders are.

26. n.a. "Faith-based finance: The whys and wherefores of Islamic finance," The Economist, Sep 4th 2008, accessed online on 23 May 2012; http:/www. economist.com/node/12052679

27. Chapra, Umer M., Towards a Just Monetary System, The Islamic Foundation, 1985, p. 71.

28. Habib Ahmed, "Islamic Financial System and Economic Growth: An Assessment," p. 18, accessed online on 15 June 2011, <islamiccenter.kau.edu. sa/.../Islamic\%20Fin.\%20System $\% 20$ and $\% 20$ Econ $\% 20$ Growth $\% 20$ by $\% 20$ Habib\%20Ahmed.doc $>$

29. Many subprime borrowers had ARMs, or adjustable rate mortgages. The interest rates on such mortgages fluctuate with market rates.

30. These arguments have been developed in the following papers: "Understanding the Causes of the Debt-Crisis: Interest-based lending," ICR, Vol. 3, No. 4, July 2012; "The Pitfalls of Riba or Interest-based Financing," ICR, Vol. 4, No. 1, January 2013; "Risk Sharing, Transfer and Management," ICR, Vo. 4, No. 2, Apr. 2013; "Debt and Economic Activity," ICR, Vol. 4, No. 3, July 2013; "Enhancing Cyclical Stability by Interest-free Banking," ICR, Vol. 5, No. 3, July 2014.

31. Schiff, Peter Euro Pacific Capital Inc., accessed online on 14 October 2014, $<$ http://www.europac.net/>

32. The price of a house can be several times higher when sold on credit by a financial institution than when sold for cash by a construction company. 
33. A small increase - specified by the law - could be permitted to compensate sellers for higher expenses caused by having to administer some of their sales on credit.

34. Effectively the prices would be lower due to the fact that bank interest would no longer be factored into them. In housing, for example, in which the credit price of a house can be as much as $200 \%$ higher than the cash price, this would effectively mean a discount of up to $67 \%$ from the credit (bank) price of the house. Such a steep reduction could hardly fail to stimulate the demand for houses.

35. As a result of lending most of their depositors' money to borrowers, banks are left with only a small amount of money (commonly less than $3 \%$ of all deposits) in the form of cash to meet unexpected withdrawals.

36. Humayon A. Dar and John R. Presley, "Lack of Profit and Loss Sharing in Islamic Banking: Management and Control Imbalances," International Journal of Islamic Financial Services Vol. 2 No. 2, September 2000, p. 4, accessed online on 20 June 2014; $<$ http://www.iefpedia.com/english/wp-content/uploads/2009/09/ international-journal-of-ISLAMIC-FINANCIAL-SERVICE.pdf>

37. A tax of $1 \%$ on the nominal value of derivatives would raise a great deal of revenue for governments, and thus enable them to repay debts. The notional value of derivatives stands at more than USD 400 trillion globally. 